\title{
Understanding Indonesian People through Literature: Indigenous Psycho-Sociology Perspectives
}

\author{
Anas Ahmadii, ${ }^{1,}$, Darni ${ }^{1}$ and Bambang Yulianto ${ }^{2}$ \\ ${ }^{1}$ Department of Indonesian Laguage and Literature, Universitas Negeri Surabaya, Indonesia \\ ${ }^{2}$ Department of Javanesse Language and Literature, Universitas Negeri Surabaya, Indonesia
}

\begin{abstract}
Indigenous studies are currently attracting humanities researchers, one of which is the field of literature. Literary researchers explore the locality contained in literary texts through the perspective of indigenous studies. In this regard, this study explored Indonesian literature through the perspective of indigenous studies. The theory used in this study was literary criticism associated with indigenous psychology and indigenous sociology. The data source used was the Rafilus novel written by Budi Darma. The research method used was qualitative because the researchers emphasized the interpretation of the text. Data analysis techniques included the stages of indexation, reduction, exposure, and interpretation. The results showed that the character Rafilus displays the psychological side of indigenous people of Java through segmentation: friendliness dan politeness in life, self-awareness in life, a simple life desire, and loves to learn.
\end{abstract}

Keywords: Indonesian literature, literary criticism, indigenous psycho-sociology, social-culture.

\section{INTRODUCTION}

In the last thirty years, literary studies have not only examined literary canon works, but also popular literature. The trend happened due to the emergence of the postmodernism wave (2019) which also has an impact on the current literary situation. Moreover, literary studies are not only explored through monodisciplinary perspectives but also more evolved and studied through interdisciplinary perspectives, including ecocritics (Garrard, 2012), ecopsychology (Fisher, 2013), psychogeography (Coverley, 2018), trauma (Ahmadi, 2021; Davis \& Meretoja, 2020), criminology (Ahmadi, 2020a), education (2019, 2020b) and cultural studies (Parker, 2020). The changes showed that the development of literary studies is currently very dynamic, but it is necessarily needed so that literary studies can give contributions in the era of globalization that is full of complexity. The development of literary studies that can be explored through other scientific disciplines cannot be separated from the essence that literature is a vast and mysterious area that can be entered by various scientific disciplines.

Nowadays, literary studies are developing towards international, transnational, and global studies. Naturally, this is a linkage of the current development of science that is looking for global power to solve global problems as well. However, on the other hand, literary studies also seek to strengthen the studies that focus on national and local contexts. It is crucial to

*Address correspondence to this author at the Department of Indonesian Laguage and Literature, Universitas Negeri Surabaya, Indonesia;

E-mail: anasahmadi@unesa.ac.id explore the uniqueness of literature that is related to its essence in a particular country, for example, literature that comes from the USA, Europe, and Asia surely will bring out its own uniqueness and diversity. The literature of each state has its own characteristic that is not owned by literature from another state or as well known as global-local. Modern people are required to know global things but should not forget about local things as well. The global-local philosophy cannot be forgotten in order to promote the local to the global level (Ghose \& Mukherjee, 2008) so that a country can continue to exist in the global era. A study conducted by Nakamura (2015) concerning indigenous studies showed that this study is very important to recognize the indigenous people of a country. Moreover, the study is also important in terms of bringing justice to indigenous and non-indigenous communities.

Regarding literature, one of which is Indonesian literature, surely has its values in terms of local characteristics. However, the local characteristics in literature are not only owned by Indonesian literature, but universally, every literature has its local characteristics. The study of local characteristics in literature can be explored through the perspective of indigenous studies. In this case, this study is more focused on indigenous psychology. In the last five years, the researcher who linked literature and indigenous was Andindilile (2019), specifically the one that studied literature related to indigenous in Africa. The study linked literature with the native languages of Africans. Other researchers, Adamson \& Monani (2017), discussed literature concerning ecocritics and indigenous. Moreover, Moore (2019) also explored

(c) 2021 Lifescience Global 
indigenous writers in South Australia. The study demonstrated the existence of writers from South Australia in producing literary works in form of poetry. They found that literature from an ecocritical perspective wants to elevate the existence of marginalized indigenous people and the environment of indigenous people who were oppressed by foreigners or colonizers.

In connection with the fact explained above, to the researcher's knowledge, no researcher has examined Indonesian literature using the perspective of indigenous psychology that uses indigenous studies as the main umbrella. Meanwhile, Indonesian literature as the literature in the Asian region has many topics related to indigenous. Thereby, in this study, the researchers raised the study of Indonesian literature through the perspective of indigenous studies. The researchers focused on a novel by Budi Darma entitled Rafilus. Through this study, the researchers hope that this study can contribute to the development of literary studies in Indonesia. Furthermore, the results of this study are expected to be useful for teachers and lecturers who teach literary criticism courses as a reference and learning support materials.

\section{LITERATURE REVIEW}

\section{Literary Criticism, Psychology, and Indigenous Studies}

Initially, literary criticism focused more on the canon theory which was already solid and tested. However, in its development, literary theory has undergone rapid changes and currently leads to newer and interdisciplinary studies (Goumari, 2015; Federici, 2003). In interdisciplinary literary studies, literature has no longer referred to canonism but is exploring how literature can be studied through contemporary perspectives.

One of the interesting areas of literary criticism is psychology. As a study of human behavior, psychology can be used to explore literary criticism (Wellek \& Warren, 2019; Lee \& Seed, 1992). The study of psychology in literature was originally pioneered by psychoanalysis. The most influential influence in literature is the ideas of Freud (1989) relating to the psychology of unconsciousness and the study of dreams (Freud, 2020). Both of Freud's ideas have entered a lot of literary contexts. In today's development, psychology has no longer led to canonization but in interdisciplinary contexts, so is the study of literary psychology. The study of literary psychology has also changed to the study of interdisciplinary literary psychology, for example, ecopsychology, trauma psychology, masculinity psychology, feminity psychology, to LGBT psychology. The development of the study of literary psychology is one of the important breakthroughs in literary criticism because it is expected to be able to explore psychology in literature more deeply. Moreover, interdisciplinary studies of literary psychology can provide more practical solutions in terms of psychological problems that are explored through literary context.

One of the psychological studies that are currently emerging is indigenous psychology. In this context, literature can be linked to the local psychology of a particular society with certain peculiarities. Indigenous psychology is a part of indigenous studies. Indigenous psychology is currently being discussed a lot to raise issues related to the locality of the society in some regions. As a field of study, indigenous psychology is not like monodisciplinary psychology that requires expertise in psychology, for example, only psychologists that can be the researchers. In this case, indigenous psychology researchers can come from other scientific disciplines that have concerns in the field of science they are currently pursuing.

Indigenous is a field of study related to certain communities that focuses on the uniqueness, localization, and characteristics of the society (Sillitoe, 2016), both in a country and cross-country contexts (Goldie, 2014). Indigenous wants to raise traditional traditions (Andersen \& O'Brien, 2017; Ray, 2012) in the context of contemporary, religion or spirituality (Neeganagwedgin, 2013), and kinship systems. Banerjee (2016) showed that indigenous are related to indigenous peoples in a region. This study raised traditionalism in modern society. Nowadays, modern people are starting to leave the traditional world. In fact, traditional is not necessarily out of date, for example, traditional medicine. Some traditional medicine that comes from herbs has become an alternative in modern medicine.

Indigenous studies are a field of study that began to be widely discussed in the 1990s. Nevertheless, the ideas of indigenous studies have been started a long time ago, especially in the context of anthropology, for example, Geertz $(1965,1975)$ conducted studies about the socio-cultural and religious life of Java, Indonesia. As an anthropologist, he explored in-depth the life of Javanese-Indonesian people through the lens of 
anthropology (which cannot be separated from the indigenous Javanese-Indonesian people). In its current development, indigenous studies are not only included in the area of anthropology but also include various other disciplines, from psychology, linguistics, law, to literature.

In connection with indigenous studies, Konadu (2009) explained that medical treatment in the indigenous context is very abundant, for example, in Ghana that has a lot of forests, many treatments can be taken from these forests starting from the roots, seeds, leaves, to the tree. Traditional and indigenous medicine is a treatment that has minimal risks and side effects because it came from plants. In the context of social-psychology, Kim \& Yang (2011) showed that traditional society in the indigenous perspective raised local psychology that is the characteristics of the society. Moreover, the socio-cultural life of traditional societies also raised some uniqueness that other regions did not have but could also have similarities with the psychosocial-cultural society from another region. Concerning indigenous studies, Skille (2021) associated the socio-cultural life of traditional societies with the context of traditional sports.

\section{Indigenous Psycho-Sociology}

Indigenous psycho-sociology is essentially related to indigenous which is associated with the context of psychology and sociology. Referring to the views of Cavalletto \& Chalcraft (2016), Clarke (2006), the term psycho-sociology is an intersection between psychology and sociology in understanding a reality that exists in society. Hilton (2011) stated that the study of psycho-sociology was initially pioneered by people from the disciplines of psychology and sociology in solving psychological problems in society. Figures who tried to combine psychology and sociology, for example Fromm (1970) who linked psychoanalysis and Marxian sociology.

Indigenous psycho-sociology seeks to understand the psychological context that exists in society which is associated with uniqueness, locality, ancestral heritage, or tradition. If indigenous psychology prioritizes psychological issues, mental processes, and individual behavior dan Begitu juga dengan indigenous sociology yang lebih mengarah pada konteks kemasyarakatan saja (Howard-Wagner, Habibis, \& Petray, 2012) tanpa memperhatikan konteks psikologi masyarakat, indigenous psycho-sociology prioritizes how individuals behave in society, both in relation to other people or with communities/society groups.

\section{METHODOLOGY}

The method used in this study is qualitative because it used more verbal data exposure (Merriam \& Grenier, 2019) and was based on the researchers' interpretation (Creswell, 2007). The researchers, as interpreters, uncovered the meaning contained in literary texts. The uncovering of meaning in literature was carried out in two stages, namely the text stage and the symbol stage. At the text stage, the researchers interpreted the surface of the literary texts, meanwhile in the symbol stage, the researchers interpreted the inside of the literary texts that were related to the essence. The data source used is the Rafilus novel written by Budi Darma. The novel was published by Balai Pustaka (1988). The researchers used data in the form of text which was related to the author's monologue, dialogue, and narrative which has relevance to indigenous studies.

The data collection technique was carried out by researchers using library research. The data analysis technique in this study referred to the views of Ritchie \& Lewis (2018) relating to the stages: indexation and data reduction; data description; data exposure; and data interpretation. For the data to be tested, researchers conducted data validity by internal and external validation. Internal validation was carried out by researchers as the key instrument. As for external validity, the researchers conducted discussions with experts in the field of literature. Additionally, researchers also carried out a research process with a simultaneous and flow model. Thus, the researchers hope that the research results can be more comprehensive.

\section{RESULTS AND DISCUSSION}

\section{Friendliness and Politeness}

The character named Rafilus was described by the author as having a friendly and kind character. In the local psychology of Javanese, most Javanese people are polite, highly tolerant, and friendly figures. Javanese people as agrarians surely strengthened the friendliness. These polite and friendly attitudes are passed on to their children and grandchildren. In this manner, children and grandchildren followed the tradition of friendly and polite attitudes to others. The picture of friendliness in Rafilus can be seen in the following quote. 
Rafilus is friendly and seems to always want to be friends (Darma, 1988, 15).

Based on the quote, it appears that the author implicitly showed Rafilus has the friendly characteristic. Rafilus showed a friendly attitude when he met other people, despite the other people was a person he knew or a person he did not know. Psychologically, this showed that Rafilus is a human being who has a good and friendly personality. In Jung's view (2014), humans are figures who have masks in terms of presenting themselves when they meet other people. The masks will be used when they are with other people they just know, other people they are familiar with, or strangers. This is indeed necessary because masks do not always have negative indications.

In this context, Rafilus as a Javanese man tried to present himself as a friendly and polite human being. Digging deeper to know whether the behavior is only a mask of Rafilus, or it is his true identity, a deeper exploration of Rafilus' personality is needed. Rafilus is like most Javanese people in general who tried to show the good attitudes of Javanese people, not the other way around. Javanese people who are truly Javanese are the people who have high ethics and uphold friendliness in their relationships with other people.

\section{Self-Awareness}

Self-aware is essentially a human being who consciously understands that they are aware of what they are doing. In the psychology of Javanese people, Jatman (2000) explained that Javanese people are introspective. In this case, introspection is defined as a human being who tries to mindfully understand themselves. Being an introspective human being is not easy because to be mindful, they must have extensive knowledge and patience.

Self-awareness in Rafilus was shown in his attitude that is aware of his identity. This is what Afif (2020) called true science, which is a science that talks about "feeling". It is because the Javanese people can see themselves in a conscious state. Becoming a conscious human being is difficult and not everyone can do it. Therefore, being introspective in life is both heavy and important.

As a Javanese man, Rafilus did not question the identity of his family, which in this case is not clear. As a child, Rafilus did not understand the detail of his family history. However, he was an ordinary man who tried to accept the reality of his life. In fact, the reality was very far from expectations. The picture is shown in the following quote.

He was always trying to make himself aware that he was just alone. And forever he will be alone (Darma, 1988, 16).

The illustration above shows that Rafilus is a man who was aware of himself and he knew his identity. He did not want to think too far about who his family was because he did not know who his real family was. This showed Rafilus's self-awareness. Rafilus also did not want to be dragged into the dilemma to find his family. He was consciously aware of the reality.

The childhood of Rafilus was full of challenges and trials, he tried to follow the flow of his life. He knew that he was an orphan. Therefore, when he was in the orphanage and was subjected to frequent torture, he tried to endure it. He did not try to evade or fight back when he knew he was not wrong, but he experienced punishment. He remained strong and introspective because he was nothing and did not have any strength. The picture is shown in the following quote.

A few moments later he talked about his experience when he was tortured in an orphanage (Darma, 1988, 25).

The quote shows that Rafilus was a strong boy when he was a child. He tried to be introspective even though he was little. He knew that he did not have anyone at that time. So, when being treated at the orphanage, he did his best not to do anything wrong, resistance, or anything else that caused him to be expelled from the orphanage. He had tried to be introspective when he was a little. Indeed, in several cases, there was torture in the orphanage that caused the children to become sick, disabled, and some even died. Therefore, the figure of Rafilus as a Javanese human figure tried to convince himself that he will not be able to fight against the stronger parties. That was why he went with the flow.

Being an orphan was not an option for Rafilus. However, he accepted the fact because it was destiny. He was an orphan with all the consequences, from living in an orphanage and experiencing a lot of torture to living alone. Rafilus, as an introspective man, was trying to live life as it is. He also did not blame fate for causing his life to be an orphan.

\section{Simple Life Desires}

Javanese people live in their simplicity. They do not have too high desires. The desire appears in the adage 
"to be through and thin" (in Javanese terms: mangan ora mangan sing penting kumpul)". The saying means that Javanese people are more concerned with being together in simplicity. Javanese people prefer simply because it is one of the characteristics of the agricultural people. However, not all Javanese people are figures who like simplicity. In Rafilus, there was a Javanese human soul who liked simplicity. As a Javanese man, Rafilus was a man who longed to have children in his household.

He only hopes for what he might achieve, namely having children (Darma, 1988, 16).

Based on the quote, it appears that Rafilus is a Javanese figure who was represented by the author as a simple human being. He only wanted to have children and nothing more. In the view of Javanese people, having children is an immeasurable provision. This is also caused by the Javanese proverb which says "children are a poor man's riches". Javanese people really want to have a lot of children because, in the future, the children will become life support when they are old. Moreover, in Javanese society who mostly live from farming, they need a lot of children so they can help cultivate large tracts of land so they want to have many children.

In some facts, Javanese people who do not have children must be sad. Needless to say, almost everyone is the same way, especially those who really want to have children. In Javanese people life, they are willing to adopt a child (in Javanese term: pikat). Pikat is done so that the childless family can be triggered to have children. In other words, the adopted child has a charm so that the family who adopts the child can further have children. If one day the family has children, the charm can be returned to the biological parents or one may be raised by the family. To do this tradition, they usually choose children who come from large families or are still related by blood. This is done so that if there are problems, they can more easily solve it, especially the problems that are related to the children.

\section{Loves to Learn}

Rafilus is a Javanese man who loves to learn. People who like to learn in Javanese terms are known as Lantip, that is a person who has a bright and intelligent brain because they have learned a lot, both from reading books, discussions, and picking up the philosophy of life from nature. Being a human who loves to learn is not an easy thing because it requires great desire. A person who has a high level of activity will try to complete his business rather than learning to read books even though not all of them do.

The character Rafilus is indeed described by the narrator as a person who loves to learn. Rafilus is indeed the son of an ordinary person whose origins were unknown nor did he try to deeply understand his origins. He was happy enough to know who he was right now. The description of the character Rafilus who loves to learn is shown in the following quote.

Rafilus' house was not widened, but elongated. The middle floor of the house scattered lots of newspapers, magazines, books and papers (Darma, 1988, 12)

Based on the quote, it appears that Rafilus' character is a person who really loves to learn. He learned a lot in order to become a smart Javanese man. If he became a smart human, he would not be easily deceived or deceived by others. Being a smart human being is indeed the desire of almost everyone so that they can make themselves dignified. In this context, Rafilus loves to learn in order to reach the level called by Maslow (2007) as self-actualization. Through self-actualization, humans can become figures that have benefits for other humans (Feist, 2020) so that they no longer become individual humans, but become humanistic humans.

Lifelong learning is also inseparable from Javanese people. Javanese people learn simultaneously because life always teaches them new knowledge. Therefore, Javanese people tend to be more adaptable in the various places they live. Rafilus also explained that in order to become a wise human being like a philosopher, a person must learn because a person who has benefits for others are those who do have brains (Darma, 1988) that are bright and intelligent. If they are failed to learn, the person becomes a useless human being, either for himself or for others.

\section{CONCLUSION}

Literature is the world of the author's imagination. Literature cannot be separated from the psychological representation of the author that appears in the form of metaphors and unconsciousness. Through literature, the indigenous psychology of a certain society can emerge, either explicitly or implicitly. In this regard, the Rafilus novel written by Budi Darma raised the indigenous psychology of Javanese people. In this 
context, the character named Rafilus displayed friendly and courteous behavior when dealing with other people; have self-awareness; have a simple life desire and a simple philosophy of life, and loves to learn. The attitude, behavior, and life philosophy of Rafilus' figure are representations of local Javanese people in relation to psychological contexts.

The recommendations for this study are more directed for the next researchers so that they can explore in depth the other novels written by Budi Darma. In addition, the next researchers also can study the other novels that are related to the local psychology of Javanese people. Even further ahead, the next researchers can explore and compare the local psychology of Indonesian people contained in Indonesian literature. Indonesian literature is literature that has many psychological elements that have not been explored in depth. Therefore, simultaneous and comprehensive exploration is indispensable. In a universal context, researchers can compare indigenous psychology found in Indonesia with other countries. Thus, the results of the research can be more comprehensive.

\section{ACKNOWLEDGEMENT}

This article is part of a research (2021) funded by the Directorate of Research and Community ServiceMinistry of Research, Technology and Higher Education (DRPM-Kemenristekdikti), Indonesia, with contract number 133/SP2H/LT/ DRPM/2021

\section{REFERENCES}

Adamson, J., \& Monani, S. Eds. (2017). Ecocriticism and Indigenous Studies: Conversations from Earth to Cosmos. New York: Routledge

Afif, A. (2020). Psikologi Suryomentaraman. Yogyakarta: Ircisod.

Ahmadi, A. (2021) The Traces of Oppression and Trauma to Ethnic Minorities in Indonesia Who Experienced Rape on the 12 May 1998 Tragedy: A Review of Literature. Journal of Ethnic and Cultural Studies, 8(2),126-144. https://doi.org/10.29333/ejecs/744

Ahmadi, A. (2020a). Study of Criminal Psychology in Indonesian Literature. International Journal of Criminology and Sociology, 9, 1285-1291.

https://doi.org/10.6000/1929-4409.2020.09.147

Ahmadi, A. (2020b). Promoting Personality Psychology through Literary Learning: An Appreciative-Reflective Study. International Journal of Innovation, Creativity and Change, 11 (7):529-540, https://www.ijicc.net/index.php/volume-122020/174-vol-12-iss-8

Ahmadi, A. (2019). Teachers as Psychologist:Experience in Beginner Level of Creative Writing Classes Using Behavior Modification. International Journal of Learning, Teaching and Educational Research, 18 (12): 101-115. https://doi.org/10.26803/iilter.18.12.7
Andersen, C., \& O'Brien, J. M. (2017). Sources and Methods in Indigenous Studies.

https://doi.org/10.4324/9781315528854

Andindilile, M. (2019). The Anglophone Literary-Linguistic Continuum: English and Indigenous Languages in African Literary Discourse. Baltimore, Maryland: Project Muse, Baltimore, Md. https://doi.org/10.2307/j.ctvh8r2vh

Banerjee, M. (2016). Comparative Indigenous Studies. Heidelberg: Universitätsverlag Winter.

Cavalletto, G., \& Chalcraft, P. D. (2016). Crossing the Psycho-Social Divide: Freud, Weber, Adorno and Elias. Abingdon Taylor and Francis Ann Arbor, Michigan. https://doi.org/10.4324/9781315575148

Coverley, M. (2018). Psychogeography. Harpenden, Herts: Oldcastle Books

Clarke, S. (2006). Theory and Practice: Psychoanalytic Sociology as Psycho-Social Studies. Sociology, 40(6), 1153-1169. https://doi.org/10.1177/0038038506069855

Creswell, J. W. (2007). Qualitative Inquiry \& Research Design: Choosing Among Five Approaches. Thousand Oaks, California: SAGE Publications.

Darma, B. (1988). Rafilus. Jakarta: Balai Pustaka.

Davis, C., \& Meretoja, H. Eds. (2020). The Routledge Companion To Literature And Trauma. London: Routledge. https://doi.org/10.4324/9781351025225

Federici, C. (2003). Literary Texts \& the Arts: Interdisciplinary Perspectives. New York Washington, Oxford

Feist, G. J. (2020). Psychology. Columbus: McGraw-Hill.

Fisher, A. (2013). Radical Ecopsychology: Psychology in the Service of Life. Albany: State University of New York Press.

Freud, S. (1989). A General Selection from the Works of Sigmund Freud. New York, N.Y: Anchor Books.

Freud, S. (2020). The Interpretation of Dreams. London: Flame Tree

Fromm, E. (1970). The crisis of psychoanalysis. New York : Holt, Rinehart, Winston

Garrard, G. (2012). Ecocriticism. London: Routledge. https://doi.org/10.4324/9780203806838

Geertz, C. (1964). The Religion of Java: (New York): The Free Press of Glencoe. London: Collier-Macmillan.

Geertz, C. (1975). The Social History of an Indonesian Town. Cambridge, Mass: M.I.T. Press.

Ghose, A., \& Mukherjee, I. (2008). Glocalisation of Brands. Hyderabad, India: Icfai University Press.

Goldie, T. (2014) Trans-Indigenous: Methodologies for Global Native Literary Studies. Journal of Postcolonial Writing, 50(4), 499500. https://doi.org/10.1080/17449855.2014.898830

Goulimari, P. (2015). Literary Criticism and Theory: From Plato to Postcolonialism. London: Routledge. https://doi.org/10.4324/9780203487198

Howard-Wagner, D, Habibis, D \& Petray, T, eds. (2012). Theorising Indigenous Sociology: Australian Perspectives Workshop Proceedings, The University of Sydney, http://ses.library.usyd.edu.au/handle/2123/8630.

Hilton, D. (2011). The Emergence of Cognitive Social Psychology. In A. W. Kruglanski and W. Stroebe. Handbook of the History of Social Psychology (pp. 45-79). London: Routledge.

Jatman, D. (2000). Psikologi Jawa. Yogyakarta: Bentang

Jung, C. G.(2014). The Archetypes and the Collective Unconscious. London: Routledge. https://doi.org/10.4324/9781315725642

Kim, U., \& Yang, G. (2011). Indigenous and Cultural Psychology: Understanding People in Context. New York: Springer. 
Konadu, K. (2009). Indigenous Medicine and Knowledge in African Society. New York: Routledge.

Lee, V., \& Seed, D. (1992). The Handling of Words and Other Studies in Literary Psychology. Lewiston: E. Mellen Press.

Mármol, G. A., \& Arnao, M. J.C. Eds. (2014). Studies in Philology: Linguistics, Literature and Cultural Studies in Modern Languages. Newcastle upon Tyne, England: Cambridge Scholars Publishing

Maslow, A. H. (2007). Motivation and personality. New Delhi: Pearson Education.

Merriam, S. B., \& Grenier, R. S. (2019). Qualitative research in practice: Examples for discussion and analysis. San Francisco, CA Jossey-Bass

Moore, D. (2019). The inter-Indigenous encounter. The Journal of Common wealth Literature. https://doi.org/10.1177/0021989419857459

Nakamura, N. (2015). Being Indigenous in a Non-Indigenous Environment: Identity Politics of the Dogai Ainu and New Indigenous Policies of Japan. Environment and Planning A: Economy and Space, 47(3), 660-675. https://doi.org/10.1068/a130003p

Neeganagwedgin, E. (2013). Ancestral Knowledges, Spirituality and Indigenous Narratives as Self-Determination. AlterNative: An International Journal of Indigenous Peoples, 9(4), 322-334. https://doi.org/10.1177/117718011300900404
Parker, R. D. (2020). How to interpret literature: Critical theory for literary and cultural studies. New York : Oxford University Press.

Ray, L. (2012). Deciphering the "Indigenous" in Indigenous Methodologies. AlterNative: An International Journal of Indigenous Peoples, 8(1), 85-98. https://doi.org/10.1177/117718011200800107

Ritchie, J., \& Lewis, J. (2018). Qualitative Research Practice: A Guide for Social Science Students and Researchers. Los Angeles : SAGE

Sillitoe, P. (2016). Indigenous Studies and Engaged Anthropology: The Collaborative Moment. London: Routledge. https://doi.org/10.4324/9781315588377

Skille, E. A. (2021).Doing Research Into Indigenous Issues Being Non-Indigenous. Qualitative Research. https://doi.org/10.1177/14687941211005947

Stephan, M. (2019). Defining Literary Postmodernism for the TwentyFirst Century. Cham: Springer International Publishing. https://doi.org/10.1007/978-3-030-15693-0

Wellek, R., \& Warren, A. (2019). Theory of Literature. New York: Snova.

https://doi.org/10.6000/1929-4409.2021.10.147

(c) 2021 Ahmadi et al.; Licensee Lifescience Global.

This is an open access article licensed under the terms of the Creative Commons Attribution Non-Commercial License (http://creativecommons.org/licenses/by-nc/3.0/) which permits unrestricted, non-commercial use, distribution and reproduction in any medium, provided the work is properly cited. 